\title{
INTERACTION EFFECT OF DATE OF PLANTING, BULB SIZE AND FERTILIZATION ON YIELD AND QUALITY OF TUBEROSE PLANTS.
}

Abdalla, M. Y. A.; M. N. Sharf El-Din; A. M. Hamza and A. A. Hegazy

Veget. and Flor. Dept., Fac. of Agriculture Mansoura University Egypt.

\begin{abstract}
A field experiment was carried out on tuberose plant during 2004-2005 and 2005-2006 seasons at a private farm at Demyana near Belqas Dakahlia Governorate. The main objectives of the study were to find out the effect of using NPK compound fertilizer (19:19:19) the common name (High Fertal) fertilizer at three levels (5, 10 and $15 \mathrm{~g} /$ plant) either alone or combined with compost (150, 200 and $250 \mathrm{~g} / \mathrm{plant}$ ). Tuberose bulbs were graded into large, medium and small sizes and planting was during April, May and June of both seasons. Thus, the experiment was a split split plot design with 3 replicates. The obtained results indicated that large size bulbs planted during April and fertilized with the higher levels of NPK +compost gave the maximum number of cut spikes/ pot with more length compared to using medium or small bulbs receiving the same treatment. Large bulbs also produced spikes of more number of florets spike, more spike diameter, and the number of days from planting to opening of the $1^{\text {st }}$ florets was reduced. Also, higher levels of NPK or NPK+ compost increased N, $\mathrm{P}$ and $\mathrm{K}$ contents in the leaves of large bulbs planted during April, while the lowest contents were for June planting. Thus, it is recommended to use large size bulbs for planting during April and application of NPK at balanced levels along with compost for improvement of soil properties a matter reflexes on flower production.
\end{abstract}

\section{INTRODUCTION}

The tuberose (Polianthus tuberosa L.) family Amaryllidacea is one of the earliest cultivated plants. Once introduced to Europe, it became part of the moon garden. A collection of white or pastel flowers release an intense fragrance after dusk. One or two open blossoms will fill the air of an entire garden with pleasant fragrance.

The tuberose, a native of Mexico, is widely grown in the plains of India and blooms profusely during the summer and rains, flaunting its fragrance outdoors and indoors. Most artistic garland, floral ornaments, bouquets and buttonholes are made from these flowers. The long spike of flowers is excellent for table decoration. The flowers remain fresh for days together and bathe the atmosphere with their sweet pleasant fragrance Rose (1999).

In Egypt, tuberose flowers are very popular for local and foreign markets. Flower production begins mainly in summer, while autumn is the season for the return flower production resulting in high profits due to lack of other flowers available during this period.

For obtaining tuberose flowers of high quality, good management is of atmost importance. This includes chemical fertilization, use of composts to improve soil properties for increasing vegetative growth and flower production.

To extend the flowering season of tuberose, bulbs can be planted at different dates. Bulb size is also important and of direct effect on vegetative growth and flowering period. 
Abdalla, M. Y. A. et al.

Therefore, the present work was conducted to study the effects of using different NPK levels and compost on tuberose bulbs of different sizes at different dates of planting.

\section{MATERIALS AND METHODS}

This study was carried out during two successive seasons 2004/2005 and 2005/2006. The field experiment was located in a private farm at Gemyana village, near Belqas, Dk Governorate.

The main objectives of this study were to find out the effects of planting tuberose bulbs in three different dates, using three different bulb sizes and NPK fertilizers at different levels either alone or combined with compost in the two successive seasons.

Tuberose bulbs of the single type were obtained from a well known nursery at Barrages. The bulbs were cleaned from any adherent soil particles and damaged or infected ones were discarded. Only round bulbs were used for the experiment.

Before planting, the bulbs were washed in running water, rinsed in a fungicidal solution containing Rizolex at $0.3 \%$ for 5 minutes.

Planting the bulbs was during 3 different dates each season. The first date was April $7^{\text {th }}$, the second May $9^{\text {th }}$ and the third June $4^{\text {th }}$ in 1 st season and April $5^{\text {th }}$, May $11^{\text {th }}$ and June $11^{\text {th }}$ in the $2^{\text {nd }}$ season of study.

The bulbs were graded according to size (Diameter); Large $(6-4 \mathrm{~cm})$, Medium $(4-2 \mathrm{~cm})$ and Small $(2-1 \mathrm{~cm})$.

The experiment was a split split design with 3 replicates. There were 3 main plots representing the planting dates with sub-plots representing bulbs size and sub-plots representing the fertilization treatments. NPK compound fertilizer (19:19:19) the common name (High Fertal) was used in the experiment and the assigned amount were added $(5 \mathrm{~g}, 10 \mathrm{~g}$ and $15 \mathrm{~g})$ at 3 equal doses. The first dose was applied one month from planting, the second dose was applied before the harvest of flowers and the third dose was added after the harvest of flower. Composts used were prepared from rice straw and farm residues under airopic conditions and were applied $(150 \mathrm{~g}, 200 \mathrm{~g}$ and $250 \mathrm{~g}$ ) to the soil before planting. Analysis of the used compost to recorded in table $(\mathrm{A})$.

Table (A): Physical and chemical analysis of compost used at the experiments. *

\begin{tabular}{|l|c|l|c|}
\hline \multicolumn{2}{|c|}{ Physical analysis } & \multicolumn{2}{c|}{ Chemical analysis } \\
\hline Weight dry (1m3) & $590 \mathrm{Kg} / \mathrm{m} 3$ & Total N & $1.4 \%$ \\
\hline Weight wet $(1 \mathrm{~m} 3)$ & $730 \mathrm{Kg} / \mathrm{m} 3$ & Organic C & $25.2 \%$ \\
\hline Moisture & $24 \%$ & $\mathrm{C}: \mathrm{N}$ ratio & $1: 18$ \\
\hline $\mathrm{pH}$ & 6.6 & Ammonium N & $505 \mathrm{ppm}$ \\
\hline EC & $1.6 \mathrm{ds} / \mathrm{m}$ & Nitrate N & $315 \mathrm{ppm}$ \\
\hline O.M & $58 \%$ & Total $\mathrm{P}_{2} \mathrm{O}_{5}$ & $0.6 \%$ \\
\hline Micro-organism & $\mathrm{Nil}$ & Total $\mathrm{K}_{2} \mathrm{O}$ & $0.79 \%$ \\
\hline Nematode & $\mathrm{Nil}$ & $\mathrm{Fe}$ & $630 \mathrm{ppm}$ \\
\hline Weed seeds & $\mathrm{Nil}$ & $\mathrm{Mn}$ & $157 \mathrm{ppm}$ \\
\hline Ash & $42 \%$ & $\mathrm{Cu}$ & $30 \mathrm{ppm}$ \\
\hline \multicolumn{2}{|l}{$\mathrm{Zn}$} & $40 \mathrm{ppm}$ \\
\hline
\end{tabular}

${ }^{\star}$ Soil analysis Laboratory, Min. Agri. (2004/05) 
Soil of the plots is clay-loam of medium texture. A representing samples were taken from the depth of $(0-30) \mathrm{cm}$, and analyzed for the physical and chemical properties shown in Table (B).

Table (B): Physical and chemical analysis of experimental soil. *

\begin{tabular}{|c|c|c|}
\hline Physical analysis & $2004 / 05$ & $2005 / 06$ \\
\hline Coarse sand & 1.9 & 2.5 \\
\hline Fine sand & 17.7 & 22.6 \\
\hline Silt & 26.6 & 25.3 \\
\hline Clay & 53.8 & 49.6 \\
\hline Texture & Clayey & Clayey \\
\hline EC ds.m-1 soil past & 3.12 & 3.71 \\
\hline pH 1:2.5 & 7.85 & 7.93 \\
\hline $\mathrm{O} . \mathrm{M} \%$ & 2.89 & 2.37 \\
\hline S.p \% & 68 & 65 \\
\hline \multicolumn{3}{|l|}{ Chemical analysis } \\
\hline $\mathrm{Ca} \mathrm{CO}_{3} \%$ & 1.96 & 1.87 \\
\hline $\mathrm{N} \mathrm{ppm}$ & 47.4 & 39.3 \\
\hline $\mathrm{P} \mathrm{ppm}$ & 3.91 & 2.87 \\
\hline K ppm & 362 & 275 \\
\hline
\end{tabular}

${ }^{\star}$ Soil analysis Laboratory, Min. Agri. (2004/05)

The fertilization treatments were as the following:

1. NPK at $0 \mathrm{~g} /$ plant (control)

2. NPK at $5 \mathrm{~g} /$ plant

3. NPK at $10 \mathrm{~g} /$ plant

4. NPK at $15 \mathrm{~g} /$ plant

5. Compost at $150 \mathrm{~g} / \mathrm{plant}$

6. Compost at $200 \mathrm{~g} / \mathrm{plant}$

7. Compost at $250 \mathrm{~g} / \mathrm{plant}$

8. NPK at $5 \mathrm{~g} /$ plant $+150 \mathrm{~g} /$ plant compost

9. NPK at $10 \mathrm{~g} /$ plant $+200 \mathrm{~g} /$ plant compost

10. NPK at $15 \mathrm{~g} /$ plant $+250 \mathrm{~g} /$ plant compost

Each treatment contained 10 bulbs in 3 replicates for each date of planting (April, May and June) of the both seasons of the study.

During the two seasons of study, the experimental plots were thoroughly digged and furrows of $(1 \mathrm{~m}$. long $\times 50 \mathrm{~cm}$. wide) were made. The bulbs were planted on both sides of the furrows at $20 \mathrm{~cm}$ apart and at the depth of $7-8 \mathrm{~cm}$.

Regular agricultural practices such as irrigation and weeding were carried out when ever needed.

\section{The following determinations were carried out:}

- Number of cut spikes/plot (yield of flowers).

- Spike length $(\mathrm{cm})$ from surface of the soil.

- Spike stem diameter $(\mathrm{cm})$ at $10 \mathrm{~cm}$ from the base.

- Fresh weight of cut spike (g/plant).

- Number of florets/spike.

- Number of days from planting to opening of the first floret. 
- N, P and K content \% of the leaves according by Jackson (1967)

- Number of days from planting to opening of the first floret.

\section{RESULTS AND DISCUSSION}

It is clear from the data presented in Table (1) that number of cut spikes per plot of tuberose plant was significantly affected by date of planting and fertilization treatments. All plots produced the maximum number of spikes (10 spikes/plot) from large and medium size bulbs planted during April, May and June of both seasons. Number of cut spikes per plot was significantly reduced by using small bulbs during all dates and the application of NPK or compost in both seasons of the study respectively. This result was expected due to that small bulbs contain less reserve food and some of them failed to produce cut spikes. Patil et al. (1999) reported that application of NPK resulted in the increase of flower yield. Similar results were also obtained by Barman et al. (2003) using biofertilizers along with NPK.

Table (1): Number of cut spikes per plot of tuberose plant as affected by date of planting, size of bulbs and fertilization in 2004/05 and 2005/06.

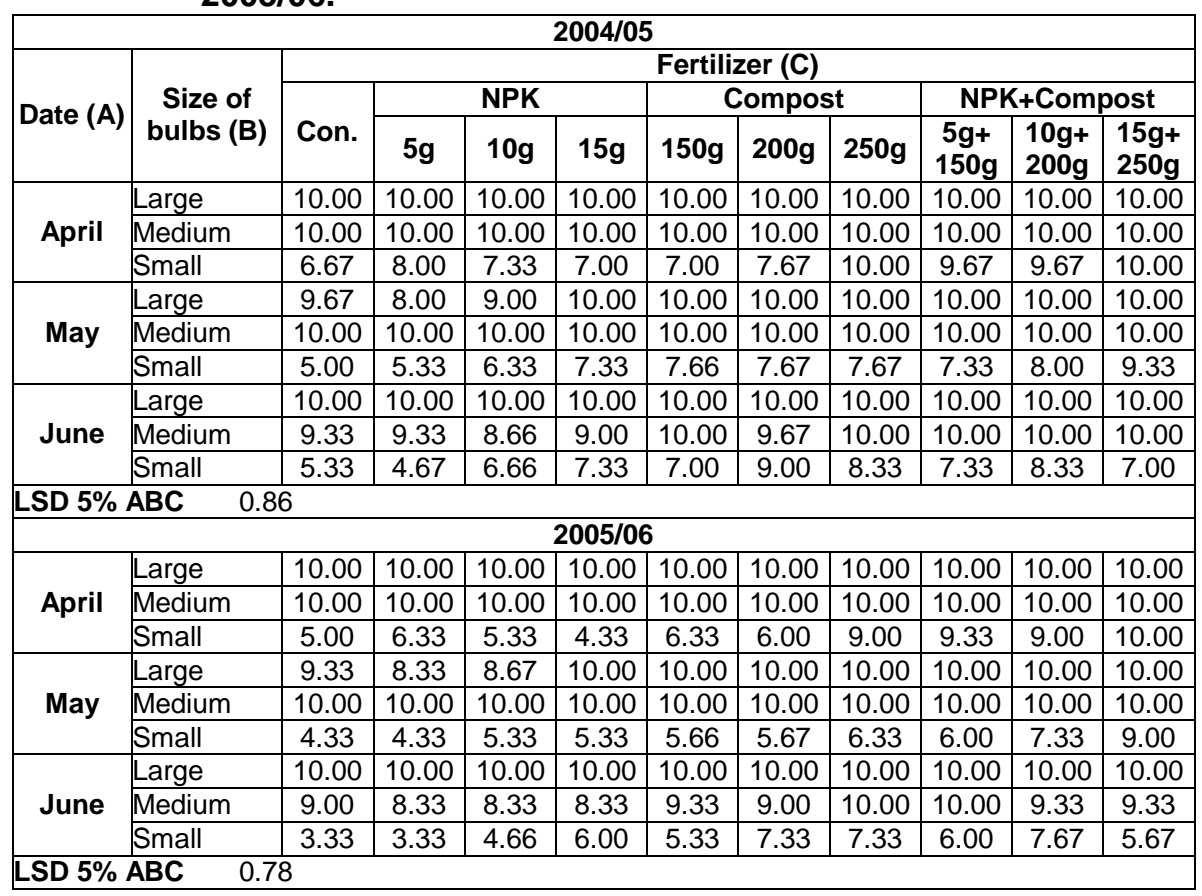

The interaction between date of planting, bulb sizes and fertilization on spike length is presented in Table (2). In the 1st season, results revealed that large bulbs planted during April and fertilized with compost $(150 \mathrm{~g}, 200 \mathrm{~g}$ and $250 \mathrm{~g} /$ plant $)$ or NPK+ compost $(5 \mathrm{~g}+150 \mathrm{~g}$ and $10+200 \mathrm{~g} /$ plant $)$ gave tuberose spikes of more length $(89.63,87.03$ and $86.33 \mathrm{~cm})$ for compost and $(87.13$ 
and $86.53 \mathrm{~cm}$ ) for NPK+ compost, with no significant difference when compared with medium bulbs. While small bulbs receiving the same fertilization treatment gave the least length. On the other hand, all bulb sizes planted during May and June gave short tuberose spikes although received the same fertilization treatment. The obtained data are true for both seasons under study. This conclusion agrees with Nagappa Desai et al. (2006) who obtained maximum spike length and superior quality flowers with only FYM application.

Table (2): Average spike length in $\mathrm{cm}$ of tuberose plant as affected by date of planting, sizes of bulbs and fertilization in 2004/05 and 2005/06.

\begin{tabular}{|c|c|c|c|c|c|c|c|c|c|c|c|}
\hline \multicolumn{12}{|c|}{$2004 / 05$} \\
\hline \multirow{3}{*}{ Date (A) } & \multirow{3}{*}{$\begin{array}{c}\text { Size of } \\
\text { bulbs (B) }\end{array}$} & \multicolumn{10}{|c|}{ Fertilizer (C) } \\
\hline & & \multirow[b]{2}{*}{ Con. } & \multicolumn{3}{|c|}{ NPK } & \multicolumn{3}{|c|}{ Compost } & \multicolumn{3}{|c|}{ NPK+Compost } \\
\hline & & & $5 g$ & $10 \mathrm{~g}$ & $15 g$ & $150 \mathrm{~g}$ & $200 \mathrm{~g}$ & $250 \mathrm{~g}$ & $\begin{array}{c}5 g+ \\
150 g\end{array}$ & $\begin{array}{l}10 \mathrm{~g}+ \\
200 \mathrm{~g}\end{array}$ & $\begin{array}{l}15 \mathrm{~g}+ \\
250 \mathrm{~g}\end{array}$ \\
\hline \multirow{3}{*}{ April } & Large & 74.76 & 81.23 & 79.53 & 77.43 & 89.63 & 87.03 & 86.33 & 87.13 & 86.53 & 83.43 \\
\hline & Medium & 80.83 & 79.33 & 79.23 & 77.33 & 87.73 & 85.03 & 84.63 & 88.33 & 86.53 & 80.93 \\
\hline & Small & 78.03 & 78.63 & 76.83 & 75.23 & 78.93 & 79.13 & 81.63 & 85.63 & 80.83 & 80.03 \\
\hline \multirow{3}{*}{ May } & Large & 69.72 & 76.57 & 80.34 & 75.32 & 85.03 & 82.42 & 81.23 & 85.39 & 85.53 & 79.70 \\
\hline & Medium & 77.67 & 76.65 & 75.90 & 79.17 & 78.66 & 80.59 & 80.33 & 84.91 & 77.81 & 78.99 \\
\hline & Small & 73.11 & 78.74 & 71.65 & 79.02 & 77.64 & 74.84 & 78.91 & 75.79 & 77.66 & 76.82 \\
\hline \multirow{3}{*}{ June } & Large & 68.98 & 71.93 & 60.42 & 64.84 & 81.04 & 68.52 & 77.73 & 77.08 & 71.94 & 74.51 \\
\hline & Medium & 70.23 & 72.25 & 63.75 & 58.26 & 72.10 & 67.83 & 68.46 & 72.33 & 69.88 & 68.36 \\
\hline & Small & 61.98 & 69.90 & 56.14 & 59.73 & 68.28 & 67.63 & 68.78 & 72.86 & 63.81 & 61.87 \\
\hline \multicolumn{12}{|c|}{$\begin{array}{|ll|}\text { LSD 5\% ABC } \quad 3.50 \\
\end{array}$} \\
\hline \multicolumn{12}{|c|}{$2005 / 06$} \\
\hline \multirow{3}{*}{ April } & Large & 71.76 & 81.42 & 78.13 & 81.79 & 91.23 & 85.99 & 82.91 & 87.70 & 80.50 & 81.30 \\
\hline & Medium & 76.88 & 81.79 & 83.98 & 87.20 & 84.05 & 82.05 & 75.05 & 75.50 & 81.00 & 81.71 \\
\hline & Small & 77.49 & 83.58 & 81.49 & 86.73 & 86.99 & 75.85 & 73.50 & 73.70 & 74.50 & 72.54 \\
\hline \multirow{3}{*}{ May } & Large & 70.94 & 78.07 & 76.26 & 72.50 & 82.05 & 85.97 & 75.66 & 82.85 & 79.63 & 75.18 \\
\hline & Medium & 65.53 & 74.56 & 72.49 & 70.92 & 77.79 & 74.48 & 76.27 & 76.74 & 77.46 & 74.39 \\
\hline & Small & 68.29 & 69.20 & 61.90 & 69.38 & 70.54 & 73.12 & 69.87 & 71.38 & 68.45 & 69.63 \\
\hline \multirow{3}{*}{ June } & Large & 50.34 & 67.87 & 43.66 & 58.79 & 73.36 & 66.82 & 64.10 & 74.28 & 63.09 & 73.93 \\
\hline & Medium & 43.10 & 68.86 & 51.43 & 59.58 & 68.17 & 66.93 & 59.03 & 61.76 & 63.99 & 69.02 \\
\hline & Small & 48.04 & 65.97 & 45.42 & 48.34 & 66.76 & 58.14 & 53.91 & 61.53 & 59.08 & 58.79 \\
\hline \multicolumn{12}{|c|}{ LSD 5\% ABC 5.92} \\
\hline
\end{tabular}

Data in Table (3) showed the interaction between date of planting, size of bulbs and fertilization on weight of tuberose spikes. It is clear that large bulbs responded greatly to NPK + compost $(5 \mathrm{~g}+150 \mathrm{~g} / \mathrm{plant})$ and produced spikes of more weight $(92.20 \mathrm{~g})$ followed by compost $(150 \mathrm{~g} / \mathrm{plant})$ which produced a spike weight of $(89.58 \mathrm{~g})$. The obtained data had a similar trend for both seasons under study. This was true for June planting which means that the date of planting is not greatly effective, but the better effect is related to size of bulbs and compost application. Patil et al. (1999) and Barman et al. (2003) 
Abdalla, M. Y. A. et al.

Table (3): Fresh weight ( $\mathrm{g} / \mathrm{plant})$ of cut spikes of tuberose plant as affected by date of planting, size of bulbs and fertilization in $2004 / 05$ and 2005/06.

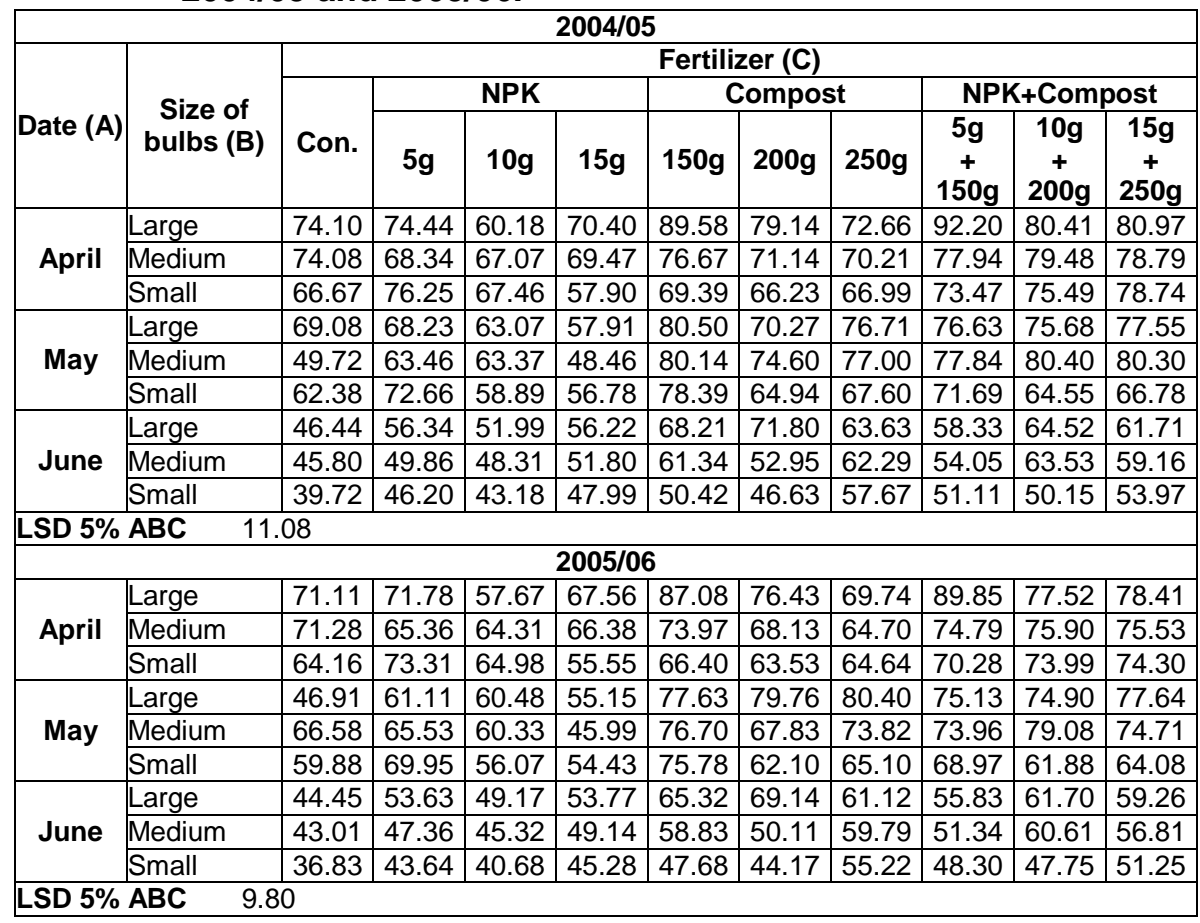

Data presented in Table (4) showed the interaction between date of planting, size of bulbs and fertilization on spike diameter of tuberose plants. During both seasons of the study, it is clear that large size bulbs planted during April responded greatly to compost (150g and $200 \mathrm{~g} / \mathrm{plant}$ ) and NPK + compost $(5 \mathrm{~g}+150 \mathrm{~g}$ and $10 \mathrm{~g}+200 \mathrm{~g} / \mathrm{plant})$ treatment and produced tuberose spikes of more stem diameter $(1.40$ and $1.31 \mathrm{~cm})$ for compost and $(1.26$ and $1.34 \mathrm{~cm}$ ) for NPK + compost with no significant difference when compared with medium bulbs. This could be explained by that compost play an important role in improving physical properties of the soil and make the nutrients in the plant medium more available. On the other hand, small bulbs produced tuberose spikes of the least stem diameter when planted during June of both seasons of the study. The obtained results are in agreement with those reported by Gurav et al. (2005). 
Table (4): Average spike diameter in $\mathrm{cm}$ of tuberose plant as affected by date of planting, size of bulbs and fertilization in 2004/05 and 2005/06.

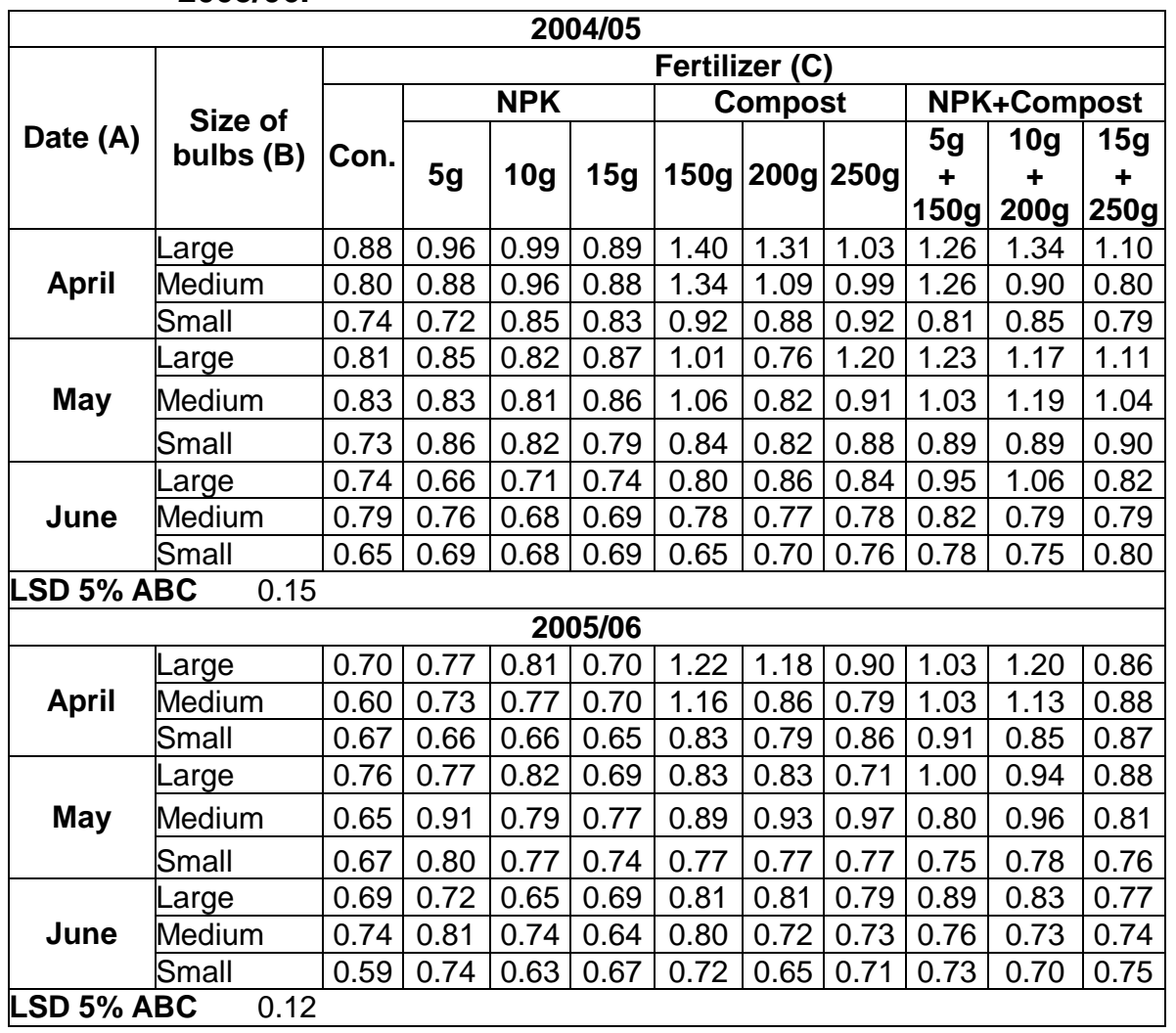

The interaction between date of planting, size of bulbs and fertilization on number of florets per spike is presented in Table (5). During both seasons of study it is clear that large size bulbs planted during April and May treated with compost (150g and $200 \mathrm{~g} / \mathrm{plant})$ and NPK + compost $(5 \mathrm{~g}+150 \mathrm{~g}$ and $10 \mathrm{~g}+200 \mathrm{~g} / \mathrm{plant}$ ) gave more number of florets per spike (39.90 and 38.80 florets) respectively for compost and (41.40 and 41.50 florets) respectively for NPK + compost. The effect of compost is obvious because of its beneficial effect in improving soil conditions. Similar results were also obtained by ElShahat, N. S. (1993) and Badawy (1998) who found that sand/composted leaves increased number of florets per spike of tuberose plants. 
Abdalla, M. Y. A. et al.

Table (5): Average number of florets per spike of tuberose plant as affected by date of planting, size of bulbs and fertilization in 2004/05 and 2005/06.

\begin{tabular}{|c|c|c|c|c|c|c|c|c|c|c|c|}
\hline & & & & & $2004 /$ & & & & & & \\
\hline & & & & & & Fertili & izer (C) & & & & \\
\hline & Size of & & & NPK & & & ;ompo & & NPK & + Com & post \\
\hline (A) & $\begin{array}{c}\text { bulbs } \\
\text { (B) }\end{array}$ & Con. & $5 \mathrm{~g}$ & $10 \mathrm{~g}$ & $15 g$ & $150 \mathrm{~g}$ & $200 \mathrm{~g}$ & $250 \mathrm{~g}$ & $\begin{array}{c}5 g \\
+ \\
150 a\end{array}$ & $\begin{array}{c}10 \mathrm{~g} \\
+ \\
200 \mathrm{~g}\end{array}$ & $\begin{array}{c}15 \mathrm{~g} \\
+ \\
250 \mathrm{a}\end{array}$ \\
\hline & Large & 30.80 & 33.90 & 32.80 & 32.90 & 39.90 & 38.80 & 35.80 & 41.40 & 41.50 & 38.00 \\
\hline April & Medium & 26.60 & 32.00 & 31.20 & 32.40 & 37.40 & 37.80 & 35.00 & 37.40 & 35.20 & 33.40 \\
\hline & Small & 27.70 & 28.70 & 30.40 & 29.90 & 33.20 & 34.40 & 32.90 & 34.20 & 33.00 & 33.50 \\
\hline & Large & 29.50 & 30.60 & 31.60 & 30.80 & 40.30 & 37.20 & 37.10 & 40.20 & 35.70 & 35.60 \\
\hline May & Medium & 26.70 & 28.10 & 26.70 & 25.30 & 36.20 & 35.70 & 30.50 & 35.40 & 34.50 & 33.20 \\
\hline & Small & 21.10 & 26.60 & 30.20 & 27.60 & 34.80 & 33.90 & 28.10 & 34.70 & 31.00 & 28.00 \\
\hline & Large & 22.40 & 35.30 & 30.80 & 29.30 & 35.60 & 36.70 & 32.70 & 35.50 & 33.90 & 34.10 \\
\hline June & Medium & 24.70 & 35.40 & 31.40 & 25.80 & 34.90 & 35.30 & 34.60 & 34.90 & 32.70 & 33.30 \\
\hline & Small & 21.60 & 29.20 & 25.70 & 25.20 & 34.80 & 33.40 & 28.70 & 31.60 & 30.70 & 32.30 \\
\hline -SD 5\% & . ABC & 2.79 & & & & & & & & & \\
\hline & & & & & 200 & & & & & & \\
\hline & Large & \begin{tabular}{|l|}
28.70 \\
\end{tabular} & 31.8 & & 30.80 & & & & & 39.40 & 35.90 \\
\hline April & Medium & 24.30 & 29.90 & 29.10 & 30.30 & 34.10 & 35.70 & 32.90 & 38.10 & 33.10 & 31.30 \\
\hline & Small & 25.60 & 26.60 & 28.30 & 27.80 & 31.10 & 32.30 & 30.80 & 32.10 & 30.90 & 31.40 \\
\hline & Large & 27.40 & 28.50 & 29.50 & 28.70 & 38.20 & 35.10 & 35.00 & 35.30 & 33.80 & 32.00 \\
\hline May & Medium & 24.60 & 26.00 & 28.10 & 25.50 & 33.50 & 33.60 & 28.40 & 33.30 & 32.40 & 31.10 \\
\hline & Small & 19.00 & 24.50 & 24.60 & 23.20 & 32.70 & 31.80 & 26.00 & 32.60 & 28.90 & 25.90 \\
\hline & Large & 20.30 & 33.20 & 28.70 & 27.20 & 35.30 & 34.60 & 30.60 & 33.40 & 31.80 & 32.90 \\
\hline June & Medium & 22.60 & 33.30 & 29.30 & 23.70 & 32.80 & 33.20 & 32.50 & 32.80 & 30.60 & 31.20 \\
\hline & Small & 19.70 & 28.20 & 23.60 & 23.10 & 32.70 & 31.30 & 26.60 & 29.50 & 28.60 & 30.20 \\
\hline & $6 \mathrm{ABC}$ & 3.67 & & & & & & & & & \\
\hline
\end{tabular}

The interaction of date of planting, size of bulbs and fertilization on number of days from planting to opening of the first floret is presented in Table (6). It is clear that large bulbs planted during April responded greatly to fertilization with compost $(150 \mathrm{~g}, 200 \mathrm{~g}$ and $250 \mathrm{~g} /$ plant) or NPK + compost $(5 \mathrm{~g}+150 \mathrm{~g}, 10 \mathrm{~g}+$ $200 \mathrm{~g}$ and $15+250 \mathrm{~g} /$ plant) since the time needed for opening of the floret on the spike was the least $(66.67,67.00$ and 65.67 days) for compost and $(66.00$, 64.67 and 65.33 days) for NPK+ compost in the 1st season. On the other hand, small bulbs planted during May or June and received the same treatment of compost or NPK + compost took longer time for the opening of the first florets on the spike. Pathak et al. (1980) found that number of days required for $100 \%$ sprouting was reduced for large size bulbs. Also, Ramesh Kumar et al. (2003) reported that large bulbs resulted in the earliest spike emergence. 
Table (6): Number of days from planting to opening of the first floret of tuberose spike as affected by date of planting, size of bulbs and fertilization in 2004/05 and 2005/06.

\begin{tabular}{|c|c|c|c|c|c|c|c|c|c|c|c|}
\hline \multirow[b]{4}{*}{$\begin{array}{l}\text { Date } \\
\text { (A) }\end{array}$} & \multirow{4}{*}{$\begin{array}{l}\text { Size of } \\
\text { bulbs } \\
\text { (B) }\end{array}$} & \multicolumn{10}{|c|}{$2004 / 05$} \\
\hline & & \multirow[b]{3}{*}{ Con. } & \multirow{2}{*}{\multicolumn{6}{|c|}{\begin{tabular}{r|r} 
Fertilizer (C) \\
& Compost
\end{tabular}}} & & & \\
\hline & & & & & & & & & \multicolumn{3}{|c|}{ NPK + Compost } \\
\hline & & & $5 \mathrm{~g}$ & $10 \mathrm{~g}$ & $15 g$ & $150 \mathrm{~g}$ & $200 \mathrm{~g}$ & $250 \mathrm{~g}$ & $\begin{array}{c}5 g \\
+ \\
150 \mathrm{~g}\end{array}$ & $\begin{array}{c}10 \mathrm{~g} \\
+ \\
200 \mathrm{~g}\end{array}$ & $\begin{array}{c}15 \mathrm{~g} \\
+ \\
250 \mathrm{~g}\end{array}$ \\
\hline \multirow{3}{*}{ April } & Large & 72.33 & 70.33 & 70.00 & 71.67 & 66.67 & 67.00 & 65.67 & 66.00 & 64.67 & 65.33 \\
\hline & Medium & 73.33 & 71.33 & 71.00 & 73.00 & 69.00 & 67.67 & 68.00 & 68.33 & 69.33 & 69.33 \\
\hline & Small & 77.00 & 76.67 & 76.00 & 75.00 & 72.33 & 74.33 & 72.00 & 72.67 & 72.33 & 72.00 \\
\hline \multirow{3}{*}{ May } & Large & 71.67 & 72.33 & 70.00 & 71.00 & 69.33 & 67.33 & 69.33 & 66.67 & 69.00 & 68.67 \\
\hline & Medium & 74.33 & 72.00 & 72.00 & 74.33 & 70.67 & 69.33 & 69.00 & 70.67 & 71.33 & 70.33 \\
\hline & Small & 75.67 & 73.33 & 72.67 & 74.00 & 75.67 & 75.67 & 74.00 & 72.33 & 71.67 & 71.00 \\
\hline \multirow{3}{*}{ June } & Large & 75.00 & 70.00 & 71.33 & 73.67 & 71.67 & 70.00 & 70.33 & 70.33 & 70.67 & 70.33 \\
\hline & Medium & 75.00 & 74.33 & 74.67 & 74.00 & 73.00 & 73.00 & 73.33 & 71.67 & 71.33 & 72.00 \\
\hline & Small & 81.33 & 81.67 & 82.33 & 78.00 & 75.67 & 75.00 & 74.00 & 73.00 & 75.00 & 74.00 \\
\hline \multicolumn{12}{|c|}{ LSD 5\% ABC } \\
\hline \multicolumn{12}{|c|}{$2005 / 06$} \\
\hline \multirow{3}{*}{ April } & Large & 74.00 & 75.00 & 72.00 & 70.00 & 67.00 & 66.33 & 67.33 & 66.00 & 65.00 & 67.33 \\
\hline & Medium & 76.00 & 76.67 & 73.67 & 72.00 & 68.00 & 69.00 & 68.33 & 69.67 & 79.00 & 79.33 \\
\hline & Small & 80.33 & 79.67 & 79.33 & 78.00 & 75.00 & 78.67 & 75.67 & 74.00 & 78.00 & 77.00 \\
\hline \multirow{3}{*}{ May } & Large & 79.33 & 79.67 & 81.33 & 75.33 & 70.67 & 70.33 & 72.33 & 70.00 & 74.00 & 71.33 \\
\hline & Medium & 82.00 & 80.33 & 80.33 & 82.33 & 75.33 & 73.33 & 72.33 & 76.00 & 81.67 & 81.00 \\
\hline & Small & 85.33 & 84.33 & 79.33 & 88.33 & 73.67 & 75.00 & 74.00 & 73.67 & 85.00 & 85.67 \\
\hline \multirow{3}{*}{ June } & Large & 86.33 & 84.33 & 84.67 & 84.00 & 80.00 & 80.33 & 84.00 & 77.00 & 81.00 & 82.00 \\
\hline & Medium & 88.00 & 87.33 & 87.00 & 89.00 & 87.00 & 82.33 & 80.00 & 79.33 & 82.00 & 84.00 \\
\hline & Small & 88.00 & 89.00 & 86.00 & 82.33 & 87.67 & 87.67 & 87.67 & 82.67 & 86.00 & 88.00 \\
\hline \multicolumn{2}{|c|}{ LSD 5\% ABC } & 5.11 & & & & & & & & & \\
\hline
\end{tabular}

It is clear from the data presented in Table (7) that $\mathrm{N}$ content in the leaves of tuberose plants was increased by using higher levels of NPK or NPK + compost for large, medium and small size bulbs planted during April, May and June of both seasons of the study. The effect of NPK+ compost was more obvious than using NPK (3.38\%) alone when compared with control. Control bulbs exhibited the least $\mathrm{N}$ content in the leaves (2.36 \%). It is also, noticed that $\mathrm{N}$ content in the leaves was more for April planting followed by May and the lowest for June planting. This means that climatic conditions have affected the vegetative growth of the plants and $\mathrm{N}$ content in the leaves of all sizes receiving different fertilization treatments. Similar results were obtained by El-Maadawy (1988) and Mohanasundaram et al. (2003). 
Table (7): $N$ content \% in the leaves of Polianthes tuberosa L. as affected by date of planting, size of bulbs and fertilization in 2004/05 and 2005/06.

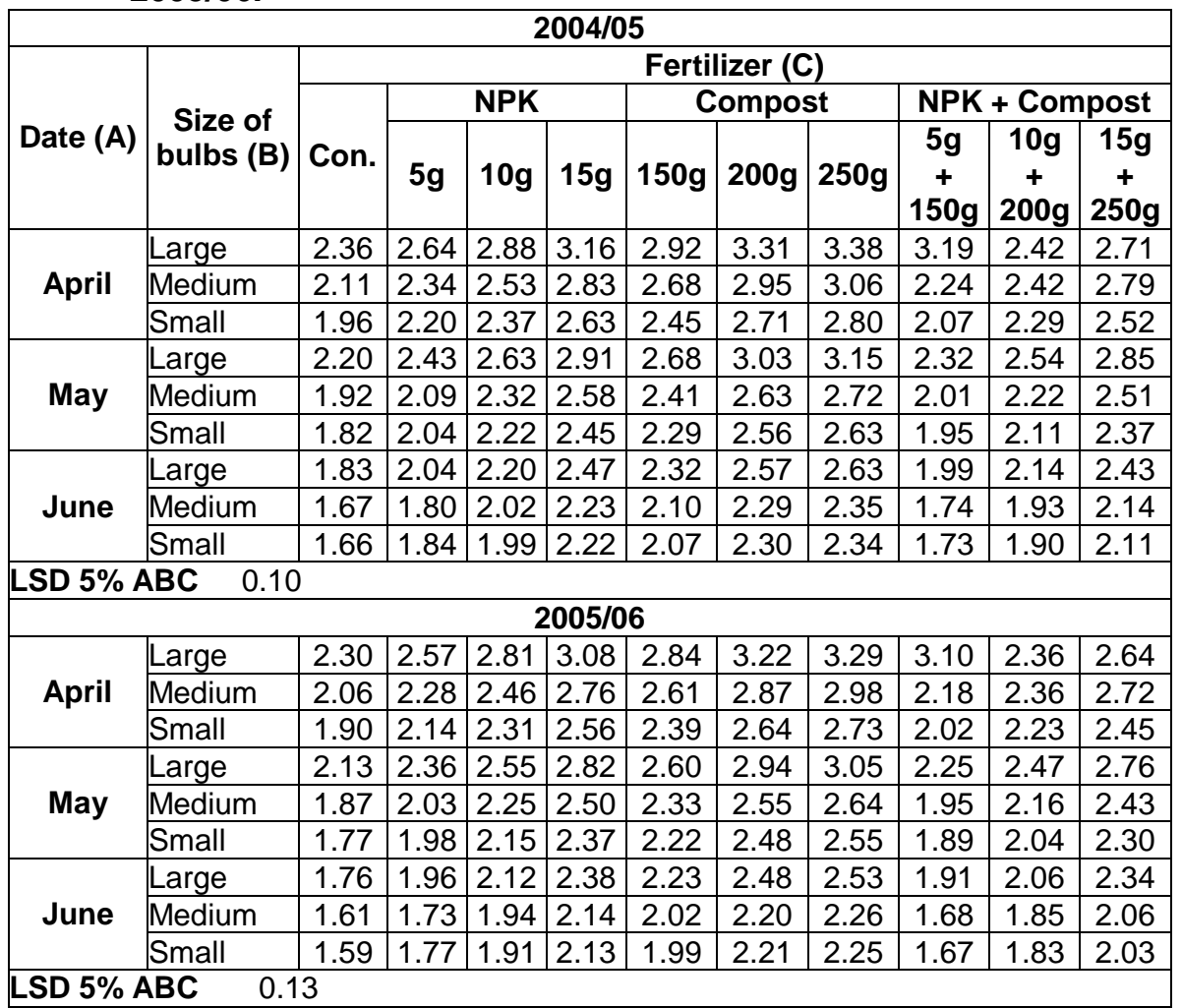

Data presented in Table (8) showed that $\mathrm{P}$ content in the leaves of tuberose plants followed the same trend of $\mathrm{N}$ content and was the least for June planting. The effect of bulb size was obvious since the P content in the leaves was higher in leaves of large size bulbs particularly during April planting. It is also noticed that $\mathrm{P}$ content in the leaves was the highest $(0.408$ $\%$ and $0.387 \%)$ by using compost at $(200 \mathrm{~g}$ and $250 \mathrm{~g} /$ plant respectively) in the 1 st season and was $(0.402 \%)$ by using compost at $(250 \mathrm{~g} / \mathrm{plant})$ in the 2nd season. The use of NPK + compost gave lower P content in the leaves compared to using NPK or compost alone. These results favor the use of compost for soil improvement which is reflected in more absorption of $\mathrm{P}$ by the plant. El-Maadawy (1988) found that $P$ content in the leaves was decreased by the fertilization treatments of $\mathrm{N}, \mathrm{P}$ and $\mathrm{K}$ applied alone or in combination. 
Table (8): $\mathrm{P}$ content \% in the leaves of Polianthes tuberosa L. as affected by date of planting, size of bulbs and fertilization in 2004/05 and 2005/06.

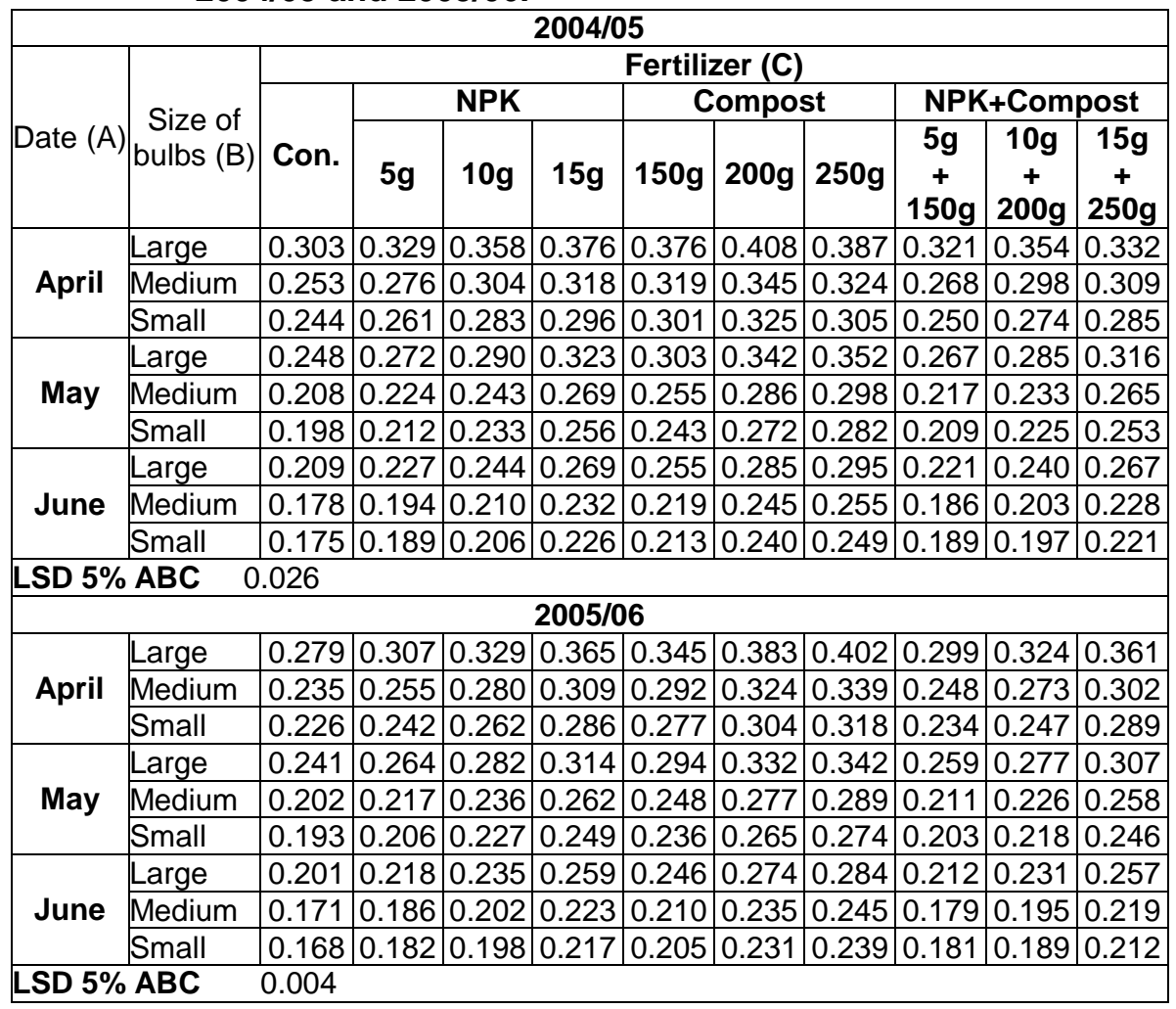

Data presented in Table (9) showed that $K$ content in the leaves of tuberose plants was higher from large bulb sizes planted during April and was the least from June planting. The effect of using compost or NPK + compost is obvious for increasing $\mathrm{K}$ content in the leaves as seen in case of $\mathrm{N}$ and $\mathrm{P}$. Using compost alone at $(200 \mathrm{~g} / \mathrm{plant})$ gave the highest $\mathrm{K}$ values in both seasons of the study $(3.86 \% \& 3.71 \%)$ respectively. The application of NPK + compost at $(5 \mathrm{~g}+150 \mathrm{~g} /$ plant) was also effective for increasing $\mathrm{K}$ content in the leaves in both seasons of the study $(3.97 \%$ \& $3.82 \%)$ respectively. The role of using compost is most important for making $\mathrm{K}$ uptake more pronounced. Some reports showed that increasing NPK level increased K content in the leaves El-Shahat (1993). 
Abdalla, M. Y. A. et al.

Table (9): $\mathrm{K}$ content $\%$ in the leaves of Polianthes tuberosa L. as affected by date of planting, size of bulbs and fertilization in 2004/05 and 2005/06.

\begin{tabular}{|c|c|c|c|c|c|c|c|c|c|c|c|}
\hline \multicolumn{12}{|c|}{$2004 / 05$} \\
\hline \multirow{3}{*}{ Date $(A)$} & \multirow{3}{*}{$\begin{array}{l}\text { Size of bulbs } \\
\text { (B) }\end{array}$} & \multicolumn{10}{|c|}{ Fertilizer (C) } \\
\hline & & \multirow[b]{2}{*}{ Con. } & \multicolumn{3}{|c|}{ NPK } & \multicolumn{3}{|c|}{ Compost } & \multicolumn{3}{|c|}{ NPK+Compost } \\
\hline & & & $5 g$ & $10 \mathrm{~g}$ & $15 g$ & $150 \mathrm{~g}$ & $200 \mathrm{~g}$ & $250 \mathrm{~g}$ & $\begin{array}{c}5 \mathrm{~g}+ \\
150 \mathrm{~g}\end{array}$ & $\begin{array}{l}10 \mathrm{~g}+ \\
200 \mathrm{~g}\end{array}$ & $\begin{array}{l}15 \mathrm{~g}+ \\
250 \mathrm{~g}\end{array}$ \\
\hline \multirow{3}{*}{ April } & Large & 2.87 & 3.06 & 3.30 & 3.63 & 3.46 & 3.86 & 3.00 & 3.97 & 3.18 & 3.51 \\
\hline & Medium & 2.41 & 2.62 & 2.80 & 3.08 & 2.88 & 3.23 & 3.23 & 3.37 & 3.39 & 3.68 \\
\hline & Small & 2.38 & 2.56 & 2.76 & 3.04 & 2.79 & 3.39 & 3.23 & 3.36 & 3.37 & 2.84 \\
\hline \multirow{3}{*}{ May } & Large & 2.49 & 2.68 & 2.88 & 3.14 & 2.99 & 3.37 & 3.31 & 3.50 & 2.81 & 3.06 \\
\hline & Medium & 2.11 & 2.31 & 2.45 & 2.69 & 2.56 & 2.87 & 2.22 & 2.96 & 2.37 & 2.63 \\
\hline & Small & 2.06 & 2.22 & 2.34 & 2.58 & 2.46 & 2.76 & 2.16 & 2.84 & 2.28 & 2.50 \\
\hline \multirow{3}{*}{ June } & Large & 1.99 & 2.13 & 2.31 & 2.51 & 2.39 & 2.69 & 2.09 & 2.78 & 2.22 & 2.44 \\
\hline & Medium & 1.82 & 1.97 & 2.11 & 2.32 & 2.22 & 2.49 & 1.71 & 2.55 & 2.06 & 2.27 \\
\hline & Small & 1.85 & 1.97 & 2.13 & 2.28 & 2.19 & 2.49 & 1.95 & 2.55 & 2.10 & 2.22 \\
\hline \multicolumn{12}{|c|}{ LSD 5\% ABC 0.26} \\
\hline \multicolumn{12}{|c|}{ 2005/06 } \\
\hline \multirow{3}{*}{ April } & Large & 2.76 & 2.94 & 3.17 & 3.49 & 3.33 & 3.71 & 2.89 & 3.82 & 3.06 & 3.37 \\
\hline & Medium & 2.32 & 2.52 & 2.69 & 2.96 & 2.77 & 3.11 & 3.11 & 3.24 & 3.26 & 3.54 \\
\hline & Small & 2.29 & 2.46 & 2.65 & 2.92 & 2.68 & 3.26 & 3.11 & 3.23 & 3.25 & 2.73 \\
\hline \multirow{3}{*}{ May } & Large & 2.39 & 2.57 & 2.76 & 3.01 & 2.87 & 3.23 & 3.18 & 3.35 & 2.69 & 2.94 \\
\hline & Medium & 2.02 & 2.22 & 2.36 & 2.58 & 2.46 & 2.75 & 2.13 & 2.84 & 2.28 & 2.52 \\
\hline & Small & 1.98 & 2.14 & 2.25 & 2.48 & 2.36 & 2.65 & 2.08 & 2.73 & 2.19 & 2.40 \\
\hline \multirow{3}{*}{ June } & Large & 1.94 & 2.08 & 2.26 & 2.45 & 2.33 & 2.63 & 2.04 & 2.72 & 2.17 & 2.39 \\
\hline & Medium & 1.78 & 1.92 & 2.06 & 2.27 & 2.17 & 2.44 & 1.67 & 2.49 & 2.02 & 2.22 \\
\hline & Small & 1.80 & 1.92 & 2.08 & 2.23 & 2.14 & 2.43 & 1.90 & 2.49 & 2.05 & 2.17 \\
\hline \multicolumn{12}{|c|}{$\begin{array}{ll}\text { LSD 5\% ABC } \quad 0.27 \\
\end{array}$} \\
\hline
\end{tabular}

\section{REFERENCES}

Badawy, O. E. F. (1998): Physiological and anatomical studies on tuberose bulbs. Ph.D. Thesis, Fac. Agric. Cairo Unvi.

Barman, D.; Datta, M.; De, L. C.; Banik, S. (2003): Efficacy of phosphatesolubilizing and phytohormone-producing bacteria on the growth and yield of tuberose in acid soil of Tripura. Indian Journal of Horticulture. Horticultural Society of India, New Delhi, India: 60: 3, 303-306. 6 ref .

El-Maadawy, E. I. I. (1988): Physiological studies on (Polianthes tuberosa L.). Plant. Ph. D. Thesis, Fac. Of Agric. Cairo Unvi.

El-Shahat, N. S. (1993): Effect of chemical fertilization and saline water irrigation on growth, flowering and chemical composition of tuberose plants. (Polianthes tuberosa L.) M. Sc. Thesis, Fac. of Agric. Cairo Univ.

Gurav, S. B.; Singh, B. R.; Desai, U. T.; Katwate, S. M.; Kakade, D. S.; Dhane, A. V.; Kanade, V. D. (2005): Influence of planting time on the yield and quality of tuberose. Indian Journal of Horticulture. Horticultural Society of India, New Delhi, India:. 62: 2, 216-217. 3 ref .

Jackson, M. L. (1967): Soil chemical analysis. Printice-Hall of India.

Mohanasundaram, S.; Dahiya, S. S.; Sukhbir Singh(2003): Effect of nitrogen and phosphorus on the nutrient content of tuberose (Polianthes tuberosa L) Haryana Journal of Horticultural Sciences. Horticultural Society of Haryana, Hisar, India: 32: 1/2, 64-66. 4 ref . 
Nagappa Desai; Vasundhara, M.; Gayithri, H. N.; Biradar, S. L. (2006): Studies on effect of spacing and fertilizer levels on flowering and concrete yield in tuberose (Polianthes tuberosa) cv. Shringars . Biomed. Society for Advancement of Medicinal and Aromatic Plants to the Mankind (SAMARPAN), Bangalore, India: 1: 2, 135-140. 8 ref .

Pathak, S.; M. A. Choudhuri and S. K. Chatterjee (1980): Germination and flowering in different size bulbs of tuberose (Polianthes tuberosa L.) Indian Journal of plant Physiology, 23(1): 47-54. (Hort. Abst. 51: 7954).

Patil, P. R.; Reddy, B. S.; Patil, S. R.; Kulkarni, B. S. (1999): Effect of community planting and fertilizer levels on growth and flower yield of tuberose (Polyanthes tuberosa L.) cv. Double. South Indian Horticulture. South Indian Horticultural Association, Coimbatore, India: 47: 1/6, 335-338. 5 ref .

Ramesh Kumar; Sheo Gobind; Yadav, D. S. (2003): Growth, flowering and bulb production of tuberose as influenced by different bulb size, spacing and depth of planting. Haryana Journal of Horticultural Sciences. Horticultural Society of Haryana, Hisar, India: 32: 1/2, 66-69. 9 ref.

Rose, Jeanne (1999): Essential Oils and Hydrosols. Frog Ltd. pp 375.

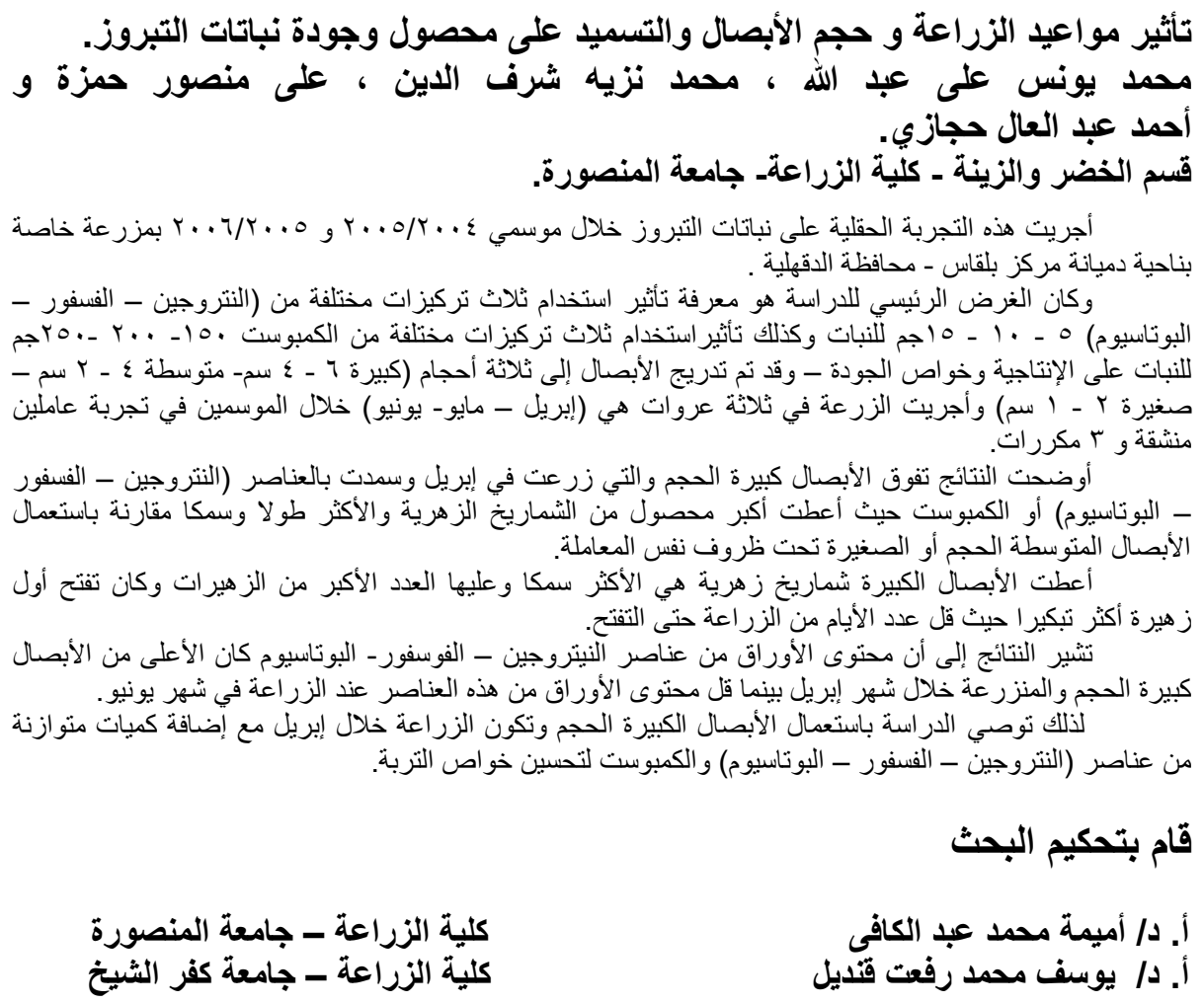


Abdalla, M. Y. A. et al. 